\title{
PENGARUH KONSELING PADA PENGETAHUAN DAN ASUPAN IBU DI WILAYAH KERJA PUSKESMAS KEBAYORAN BARU JAKARTA
}

The effect of counseling on mother's knowledge and intake in Puskesmas Kebayoran Baru Jakarta

\author{
Iskari Ngadiarti ${ }^{1}$, Moesijanti Y.E Soekatri ${ }^{1}$, Mia Srimiati², Adhila Fayasari2 ${ }^{*}$, Lina Agestika ${ }^{2}$ \\ ${ }^{1}$ Poltekkes Kemenkes Jakarta II \\ 2Program Studi Gizi, Fakultas Kesehatan Masyarakat, Universitas Binawan, Jakarta \\ E-mail: iskaringadiarti@gmail.com
}

\begin{abstract}
Providing counseling is one of the factors that increase the knowledge and actions of mothers in meeting adequate nutritional consumption. This study aimed to identify the lactation and nutrition counseling towards mother's knowledge and intake in Puskesmas Kebayoran Lama Jakarta. This research was a quasi-experimental study pre-post with a control group design. Sample collection technique used consecutive sampling with 30 respondents in each group (intervention group and control group). Counseling was given 3 times, after giving birth, a child at age 7-14 days and age 35 days. Knowledge and food intake were collected before and after the intervention. The bivariate analysis used an independent $t$ test and paired t-test with a significance level of $p<0.05$. There was a significant difference in mother's knowledge about breastfeeding between the intervention group and control group after they were given lactation counseling $(p<0.05)$. However, there was no significant difference in the mother's nutrient intake between the intervention and control group after counseled $(p>0.05)$. Lactation counseling can positively affect the mother's knowledge about breastfeeding, but not for the mother's action in consuming enough nutrient intake.
\end{abstract}

Keywords: counseling; lactation; breastfeeding

\section{ABSTRAK}

Pemberian konseling menjadi salah satu faktor yang meningkatkan pengetahuan dan tindakan ibu dalam memenuhi konsumsi gizi yang adekuat. Penelitian ini bertujuan untuk mengetahui pengaruh konseling menyusui dan konsumsi gizi terhadap pengetahuan dan asupan ibu di Puskesmas Kebayoran Lama, Jakarta. Penelitian ini merupakan penelitian eksperimental semu dengan desain pre-post dengan control group. Teknik pengambilan sampel menggunakan consecutive sampling dengan jumlah sampel 30 responden pada masing-masing kelompok (kelompok intervensi dan kelompok kontrol). Konseling diberikan sebanyak 3 kali, yaitu pada saat setelah melahirkan, bayi berusia 7-14 hari dan 35 hari. Data pengetahuan dan asupan diambil sebelum dan sesudah intervensi. Analisis bivariat menggunakan independent t-test dan paired t-test. Ada perbedaan yang bermakna pada pengetahuan ibu menyusui antara kelompok intervensi dan kelompok kontrol setelah diberikan penyuluhan laktasi $(p<0,05)$. Tidak ada perbedaan bermakna pada asupan gizi ibu antara kelompok intervensi dan kontrol setelah konseling $(p>0,05)$. Konseling laktasi berpengaruh positif terhadap pengetahuan ibu tentang menyusui, tetapi tidak untuk perilaku ibu dalam asupan gizinya.

Kata kunci: konseling, laktasi, menyusui

Doi: 10.36457/gizindo.v44i1.562

www.persagi.org/ejournal/index.php/Gizi_Indon 


\section{PENDAHULUAN}

$\mathrm{P}$ emberian air susu ibu (ASI) pada bayi penting dalam periode awal kehidupan, dimulai dari pemberian ASI eksklusif selama 6 bulan, kemudian dilanjutkan hingga anak berusia 2 (dua) tahun bersamaan dengan pemberian MP-ASI. ${ }^{1}$ Pemberian ASI eksklusif dapat memberi manfaat baik pada bayi maupun ibu. ASI mengandung zat gizi lengkap yang dibutuhkan oleh bayi, meningkatkan imunitas, mencegah penyakit infeksi, dan mencegah peningkatan mortalitas ibu dan bayi lahir. 2,3 Di Indonesia, nilai atau Angka Kematian Bayi (AKB) termasuk tinggi, jika dibandingkan dengan beberapa negara ASEAN lainnya. Human Development Report, merilis bahwa AKB di Indonesia mencapai 31/1.000 angka kelahiran. Angka Kematian Ibu (AKI) dan Angka Kematian Bayi (AKB) merupakan salah satu indikator pembangunan kesehatan dalam Rencana Pembangunan Jangka Menengah Nasional (RPJMN) 2015- 2019 dan SDGs. ${ }^{4}$

Untuk menunjang kecenderungan penurunan angka kematian bayi tersebut, pemerintah menetapkan kebijakan nasional terkait program pemberian ASI eksklusif yang dituangkan dalam Peraturan Pemerintah Republik Indonesia Nomor 33 Tahun 2012. ${ }^{5}$ Cakupan praktek pemberian ASI eksklusif di Indonesia masih cenderung rendah, yaitu sebesar 68,74 persen pada tahun 2018 dan menurun menjadi 67,74 persen pada tahun 2019. Cakupan Inisiasi Menyusui Dini (IMD) di Jakarta pada tahun 2018 sebesar 83,7 persen dan meningkat pada tahun 2019 sebesar 94,3 persen, sementara itu cakupan ASI eksklusif sebesar 45,29 persen pada tahun 2018.6,7 Angka ini masih lebih rendah dibandingkan dengan target Rencana Strategis (Renstra) 2015-2019 yaitu cakupan ASI eksklusif sebesar 50 persen pada tahun 2019.8

Pemberian ASI eksklusif dipengaruhi oleh pengetahuan, pendidikan, dukungan orang terdekat, informasi dari pertugas kesehatan, dan budaya pemberian ASI eksklusif. ${ }^{9}$ Penelitian terkait pengetahuan ibu hamil dan menyusui akan pentingnya ASI eksklusif masih rendah yaitu sebesar 51,8 persen. ${ }^{10}$ Penelitian di Yogyakarta menyebutkan ada hubungan signifikan antara pengetahuan dengan keberhasilan ASI eksklusif $(p<0,05) .{ }^{11}$
Salah satu program dalam upaya meningkatkan angka cakupan ASI ekslusif adalah dengan pemberian konseling menyusui. Konseling menyusui dapat membantu ibu mengenali kondisinya saat ini, masalah yang sedang dihadapi dan bersama-sama memilih alternatif pemecahan masalah yang sesuai dengan kondisinya saat ini tanpa adanya unsur paksaan. ${ }^{12}$ Pengetahuan tentang ASI dan kesadaran akan kesehatan ibu dan anak masih kurang. penelitian ini mengambil lokasi di daerah Cengkareng, yang mana sebagian besar ibu (78\%) mempunyai pengetahuan mengenai ASI eksklusif yang masih kurang..$^{13}$ Oleh karena itu perlu adanya pendampingan dan konseling dari petugas kesehatan. Tenaga konselor berperan penting dalam pemberdayaan ibu, peningkatan dukungan anggota keluarga serta peningkatan kualitas layanan kesehatan juga berdampak pada peningkatan cakupan ASI eksklusif di Indonesia. ${ }^{12}$

Penelitian Liliana et al. di Yogyakarta menyebutkan bahwa konseling laktasi secara signifikan dapat meningkatkan pengetahuan ibu. ${ }^{14}$ lbu yang mendapatkan konseling menyusui secara lengkap berpeluang sebesar 5,8 kali untuk memberikan ASI eksklusif dibandingkan dengan ibu hamil yang tidak mendapatkan konseling menyusui. ${ }^{15}$ Perilaku seseorang merupakan respon atau reaksi seseorang terhadap stimulus (rangsangan dari luar), yang didapat berupa pengetahuan maupun dukungan dari keluarga dan tenaga kesehatan. ${ }^{16}$ Stimulus berupa pesan kesehatan mengenai pemberian ASI eksklusif dan bagaimana mengatasi masalah yang dihadapi ibu selama proses menyusui. Diharapkan pemberian konseling ini dapat secara efektif meningkatkan pengetahuan dan tindakan ibu dalam bentuk asupan ibu yang adekuat sehingga optimalisasi kesehatan ibu dan bayinya dapat tercapai. Penelitian ini bertujuan untuk mengetahui pengaruh konseling menyusui dan konsumsi gizi terhadap pengetahuan dan asupan ibu di Puskesmas Kebayoran Lama Jakarta.

\section{METODE PENELITIAN}

Desain penelitian ini adalah quasi experimental pre-post with control group. Kelompok intervensi mendapatkan konseling 
menyusui sedangkan kelompok kontrol tidak mendapatkan konseling. Penelitian dilaksanakan selama Agustus-November (4 bulan) di Rumah Bersalin Puskesmas Kecamatan Kebayoran Lama, wilayah Jakarta Selatan.

Populasi pada penelitian ini adalah seluruh ibu hamil trimester 3 dan yang akan melahirkan di Rumah Bersalin Puskesmas Kecamatan Kebayoran Lama dengan kriteria inklusi, yaitu hamil tunggal, usia 20-40 tahun, tidak merokok, dan bersedia ikut dalam penelitian. Kriteria eksklusinya adalah ibu tidak mengikuti $>1$ kali kegiatan konseling. Teknik pengambilan sampel menggunakan consecutive sampling yaitu diambil berdasarkan urutan melahirkan dengan minimal sampel sebanyak 30 orang. Didapatkan sebanyak 60 orang, dengan 30 orang kelompok intervensi dan 30 orang sebagai kelompok kontrol. Penentuan kelompok intervensi dan kontrol ditentukan secara acak.

Kelompok intervensi mendapatkan tambahan konseling gizi ibu menyusui yang diberikan 3 kali ketika ibu melakukan kontrol pada saat bayi lahir, saat bayi berusia 7-14 hari dan saat bayi berusia 35 hari dengan durasi konseling selama 30-45 menit. Media yang digunakan yaitu modul konseling ASI Kemenkes 40 jam $^{12}$, yang meliputi rekomendasi pemberian ASI, mengapa menyusui penting, inisiasi menyusui dini, kolostrum serta ditambah dengan kecukupan asupan ibu. Konseling disampaikan oleh dua orang enumerator lulusan DIV gizi yang telah mengikuti pelatihan konseling menyusui selama lima hari. Kelompok kontrol hanya mendapatkan edukasi yang disampaikan oleh bidan yang menangani proses kelahiran. Materi edukasi tidak fokus hanya gizi tetapi juga ada keluarga berencana.

Data dikumpulkan oleh enumerator yang terlatih meliputi data karakteristik subjek (umur, pendidikan, pekerjaan, penghasilan ibu, status gizi setelah melahirkan, yaitu Indeks Massa Tubuh (IMT)), berat badan dan tinggi badan setelah melahirkan, konsumsi pangan ibu, dan pengetahuan ibu tentang ASI ekslusif. Data karakteristik diperoleh melalui wawancara menggunakan kuesioner. Berat badan diukur menggunakan timbangan digital merk GEA dengan ketelitian $0,01 \mathrm{~kg}$, tinggi badan diukur menggunakan microtoa merk GEA dengan ketelitian $0,1 \mathrm{~cm}$. Penilaian pengetahuan tentang ASI eksklusif dan data konsumsi makanan dikumpulkan dengan food recall $2 \mathrm{x}$ 24 hours berturut-turut pada sebelum konseling dan setelah konseling.

Pengolahan dan analisis data dilakukan menggunakan program statistik Analisis data dilakukan secara deksriptif dan analitik dengan batas penolakan hipotesis nol bila nilai $p<0,05$. Analisis univariat dilakukan dengan mencari rata-rata, median, modus, range untuk data numerik, dan persentase. Uji normalitas dilakukan dengan uji Saphiro-Wilk dengan hasil $p>0,05$ yang artinya distribusi bersifat normal. Data rata-rata skor pengetahuan antara kelompok intervensi dengan kelompok kontrol diuji dengan uji independen sampel t-test, sedangkan data skor pengetahuan sebelum dan setelah intervensi konseling diuji dengan uji paired sampel t-test. Penelitian ini telah lolos kaji etik dari Komite Etik Poltekkes Kemenkes Jakarta II dengan nomor LB.02.01///KE/31/287/2017.

\section{HASIL}

Karakteristik ibu dalam penelitian ini didapatkan proporsi yang seimbang antara kelompok kontrol dan intervensi. Proporsi ibu yang berusia $>=30$ tahun pada kelompok kontrol sebesar 23,3 persen, sedangkan pada kelompok intervensi sebesar 33,3 persen. Hal yang sama ditemukan pada Pendidikan ibu, Pendidikan tinggi ditemukan sebesar 66,6 persen dan 63,3 persen pada kelompok intervensi dan kontrol. Tidak ada perbedaan antara kelompok intervensi dan kelompok kontrol (Tabel 1). Sebagian besar ibu berusia di bawah 30 tahun, berpendidikan tinggi (>= SMA), merupakan lbu Rumah Tangga, dan berpenghasilan $<R p 500.000$. Status gizi ibu didominasi status gizi normal, diikuti status gizi overweight dan obesitas. Tidak ada perbedaan karakteristik ibu antara kelompok intervensi dan kontrol.

Tabel 2 menunjukan kecukupan asupan ibu menyusui. Kebutuhan energi dihitung dari nilai EAR (Estimated Average Requirement), yang merupakan 77 persen dari AKG kebutuhan ibu menyusui yaitu 1909,6 kkal, sedangkan kebutuhan protein, lemak dan karbohidrat dihitung dari AKG kebutuhan ibu menyusui. Persentase kecukupan energi hanya mencapai 78-79 persen dari EAR. Angka ini masih dalam kategori kurang (<80\% kebutuhan). Kecukupan 
zat gizi makro yang lain masih dalam kategori kurang, karena sebagian besar masih di bawah 80 persen kebutuhan. Pengetahuan ibu tentang ASI ekslusif melalui intervensi konseling menyusui disajikan pada Tabel 3. Data asupan terdistribusi normal, dan hasil uji t independen menunjukkan bahwa sebelum diberikan intervensi konseling, rata-rata skor pengetahuan antara kelompok intervensi dengan kelompok kontrol tidak berbeda secara bermakna $(p>0,05)$. Pada akhir intervensi konseling menyusui, terdapat peningkatan skor pengetahuan secara bermakna pada kedua kelompok intervensi dengan kelompok kontrol $(p<0,001)$. Peningkatan skor pengetahuan lebih besar pada kelompok kontrol, dan terdapat perbedaan bermakna pada skor sesudah diberikan skor konseling antara kelompok internvensi dan kontrol.

Tabel 1

Karakteristik Subjek dan Keluarga

\begin{tabular}{|c|c|c|c|c|c|}
\hline \multirow{2}{*}{ Karakteristik } & \multicolumn{2}{|c|}{ Intervensi $(n=30)$} & \multicolumn{2}{|c|}{ Kontrol $(n=30)$} & \multirow{2}{*}{ p-value } \\
\hline & $n$ & $\%$ & $\mathrm{n}$ & $\%$ & \\
\hline Umur ibu & & & & & $0,567^{a}$ \\
\hline$-\quad<30$ tahun & 20 & 66,7 & 23 & 76,7 & \\
\hline$-\quad \geq 30$ tahun & 10 & 33,3 & 7 & 23,3 & \\
\hline Pendidikan ibu & & & & & $1,000^{\mathrm{a}}$ \\
\hline$-\quad$ Cukup $(\leq S L T P)$ & 11 & 36,7 & 10 & 33,4 & \\
\hline - $\quad$ Tinggi ( $\geq S M A)$ & 19 & 63,3 & 20 & 66,6 & \\
\hline Pekerjaan ibu & & & & & $0,761^{a}$ \\
\hline - Tidak bekerja/ IRT & 24 & 80 & 22 & 73,3 & \\
\hline - Bekerja & 6 & 20 & 8 & 26,7 & \\
\hline Penghasilan ibu & & & & & $0,748^{a}$ \\
\hline$-\quad<R p 500.000$ & 25 & 83,3 & 23 & 76,7 & \\
\hline >Rp. 500.000 & 5 & 16,7 & 7 & 23,3 & \\
\hline Status gizi saat 1 bulan nifas & & & & & $0,173^{a}$ \\
\hline- Kurus & 2 & 6,7 & 1 & 3,3 & \\
\hline - Normal & 15 & 50,0 & 20 & 66,7 & \\
\hline - Overweight & 5 & 16,7 & 7 & 23,3 & \\
\hline - Obesitas & 8 & 26,7 & 2 & 6,7 & \\
\hline
\end{tabular}

Keterangan : ${ }^{a}$ Chi-Square test

Tabel 2

Gambaran Asupan Energi, Protein, Lemak, dan Karbohidrat Sebelum Intervensi

\begin{tabular}{|c|c|c|c|}
\hline Variabel & Asupan & Kebutuhan & \%Kecukupan \\
\hline \multicolumn{4}{|l|}{ Energi } \\
\hline $\begin{array}{l}\text { - Kontrol } \\
\text { - Intervensi }\end{array}$ & $\begin{array}{l}1503,43 \pm 395,14 \\
1525,59 \pm 356,27\end{array}$ & $1909.6^{a}$ & $\begin{array}{l}78,73 \\
79,89\end{array}$ \\
\hline \multicolumn{4}{|l|}{ Protein } \\
\hline $\begin{array}{l}\text { - Kontrol } \\
\text { - Intervensi }\end{array}$ & $\begin{array}{l}49,44 \pm 13,00 \\
48,83 \pm 13,05\end{array}$ & $80^{b}$ & $\begin{array}{l}61,80 \\
61,04\end{array}$ \\
\hline \multicolumn{4}{|l|}{ Lemak } \\
\hline $\begin{array}{l}\text { - Kontrol } \\
\text { - Intervensi }\end{array}$ & $\begin{array}{l}49,11 \pm 18,47 \\
50,82 \pm 15,56\end{array}$ & $62,2^{b}$ & $\begin{array}{l}78,95 \\
81,70\end{array}$ \\
\hline \multicolumn{4}{|l|}{ Karbohidrat } \\
\hline $\begin{array}{l}\text { - Kontrol } \\
\text { - Intervensi }\end{array}$ & $\begin{array}{l}204,47 \pm 76,36 \\
221,70 \pm 61,06\end{array}$ & $385^{b}$ & $\begin{array}{l}53,11 \\
57 ., 58\end{array}$ \\
\hline
\end{tabular}


Pengetahuan ibu tentang ASI ekslusif melalui intervensi konseling menyusui disajikan pada Tabel 3. Data asupan terdistribusi normal, dan hasil uji t independen menunjukkan bahwa sebelum diberikan intervensi konseling, ratarata skor pengetahuan antara kelompok intervensi dengan kelompok kontrol tidak berbeda secara bermakna $(p>0,05)$. Pada akhir intervensi konseling menyusui, terdapat peningkatan skor pengetahuan secara bermakna pada kedua kelompok intervensi dengan kelompok kontrol $(p<0,001)$. Peningkatan skor pengetahuan lebih besar pada kelompok kontrol, dan terdapat perbedaan bermakna pada skor sesudah diberikan skor konseling antara kelompok internvensi dan kontrol.

Tabel 3 menunjukkan adanya perubahan yang bermakna pada asupan energi, protein dan karbohidrat antara sebelum dan sesudah diberikan intervensi, bahwa asupan setelah intervensi terdapat peningkatan, sedangkan asupan lemak tidak terdapat perubahan bermakna antara sebelum dan sesudah intervensi. Dari keseluruhan asupan tidak ada perbedaan antara kelompok intervensi dan kelompok kontrol.

Tabel 3

Perubahan Pengetahuan tentang ASI Eksklusif dan Asupan Ibu sebelum dan sesudah Intervensi

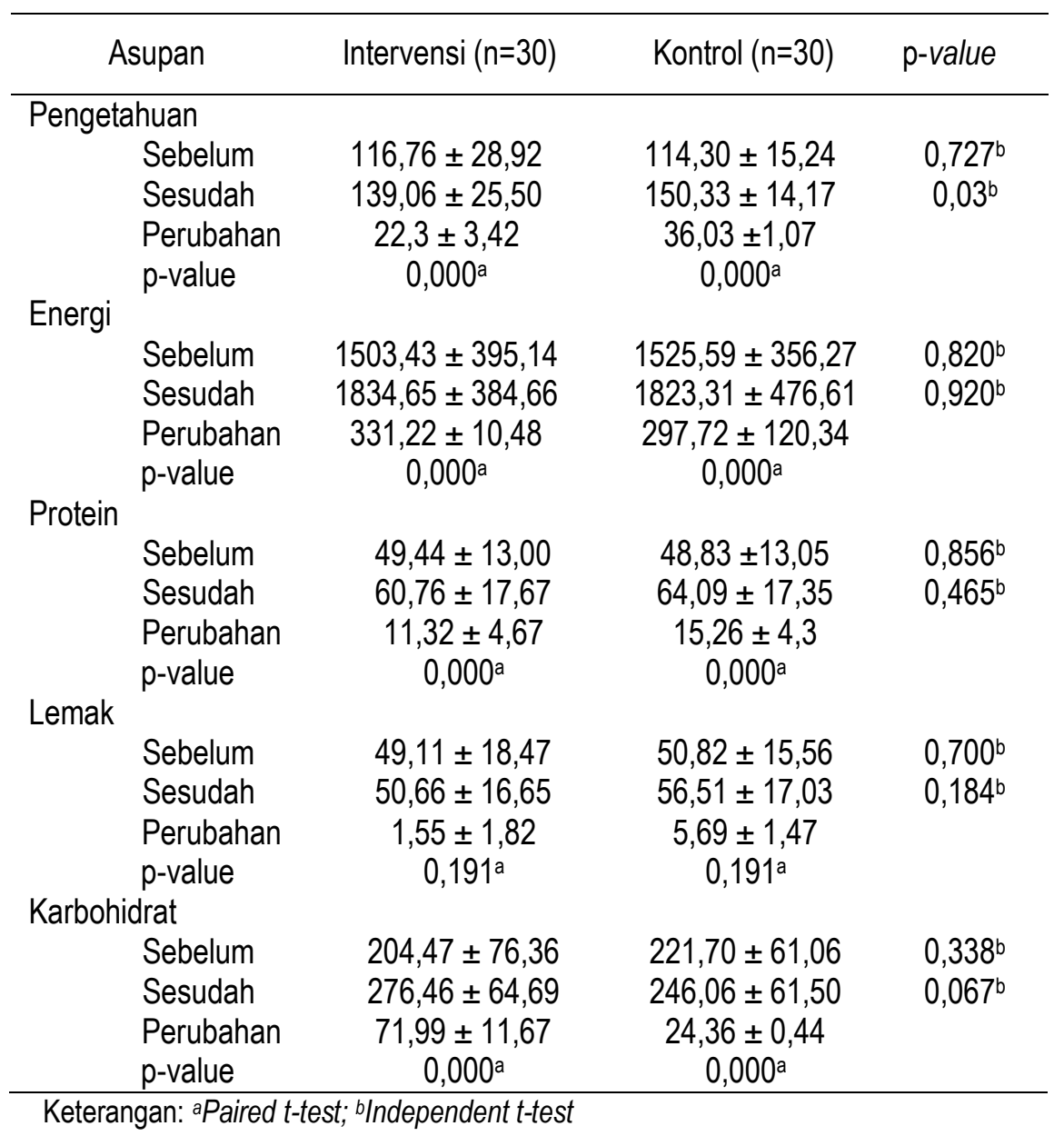


Tabel 4

Pengetahuan Ibu tentang ASI Eksklusif

\begin{tabular}{|c|c|c|c|c|c|c|c|c|}
\hline \multirow{3}{*}{ Karakteristik } & \multicolumn{4}{|c|}{ Pengetahuan awal } & \multicolumn{4}{|c|}{ Pengetahuan Akhir } \\
\hline & \multicolumn{2}{|c|}{$\begin{array}{l}\text { Kontrol } \\
(n=30)\end{array}$} & \multicolumn{2}{|c|}{$\begin{array}{c}\text { Intervensi } \\
(n=30)\end{array}$} & \multicolumn{2}{|c|}{$\begin{array}{l}\text { Kontrol } \\
(n=30)\end{array}$} & \multicolumn{2}{|c|}{$\begin{array}{c}\text { intervensi } \\
(n=30)\end{array}$} \\
\hline & $\mathrm{n}$ & $\%$ & $\mathrm{n}$ & $\%$ & $\mathrm{n}$ & $\%$ & $\mathrm{n}$ & $\%$ \\
\hline \multicolumn{9}{|l|}{ Mengetahui tentang ASI eksklusif : } \\
\hline - Ya & 23 & 76,7 & 24 & 80,0 & 30 & 100,0 & 30 & 100,0 \\
\hline & 7 & 23,3 & 6 & 20,0 & 0 & 0,0 & 0 & 0,0 \\
\hline \multicolumn{9}{|l|}{ Pengertian ASI eksklusif : } \\
\hline $\begin{array}{l}\text { - Pemberian ASI dan susu formula } \\
\text { pada usia 0-6 bulan }\end{array}$ & 2 & 6,7 & 1 & 3,3 & 6 & 20,0 & 3 & 10,0 \\
\hline - $\quad$ ASI saja pada usia 0-6 bulan & 20 & 66,7 & 21 & 70,0 & 24 & 80,0 & 27 & 90,0 \\
\hline - Tidaktahu & 8 & 26,7 & 8 & 26,7 & 0 & 0,0 & 0 & 0,0 \\
\hline \multicolumn{9}{|l|}{ Manfaat ASI: } \\
\hline - Memberi nutrisi & 2 & 6,7 & 1 & 3,3 & 4 & 13,3 & 1 & 3,3 \\
\hline - Curahan kasih saying & 2 & 6,7 & 2 & 6,7 & 2 & 6,7 & 10 & 33,3 \\
\hline - $\quad$ Sumber energi bayi & 3 & 10,0 & 2 & 6,7 & 5 & 16,7 & 7 & 23,3 \\
\hline - Pertumbuhan dan perkembangan & 6 & 20,0 & 8 & 26,7 & 5 & 16,7 & 4 & 23,3 \\
\hline Semua benar & 12 & 40,0 & 9 & 30,0 & 12 & 46,7 & 8 & 26,7 \\
\hline Tidak tahu & 5 & 16,7 & 8 & 26,7 & 0 & 0,0 & 0 & 0,0 \\
\hline \multicolumn{9}{|l|}{ Mengetahui tentang ASI pertama: } \\
\hline$-Y a$ & 11 & 36,7 & 9 & 30,0 & 17 & 56,7 & 13 & 43,4 \\
\hline - Tidak & 19 & 63,3 & 21 & 70,0 & 13 & 43,3 & 17 & 56,7 \\
\hline \multicolumn{9}{|l|}{ Manfaat kolostrum : } \\
\hline - Meningkatkan daya tahan tubuh & 19 & 65,5 & 16 & 53,3 & 21 & 70,0 & 17 & 56,7 \\
\hline - Membuat bayi cepat kenyang & 2 & 6,9 & 3 & 10,0 & 2 & 6,7 & 2 & 6,7 \\
\hline - Memperlancar produksi ASI & 1 & 3,4 & 3 & 10,0 & 1 & 3,3 & 3 & 10,0 \\
\hline - Tidak ada manfaat & 2 & 6,9 & 6 & 20,0 & 0 & 0,0 & 0 & 0,0 \\
\hline - Tidak tahu & 6 & 13,6 & 2 & 6,7 & 6 & 20,0 & 8 & 26,7 \\
\hline
\end{tabular}

Berdasarkan Tabel 4 dapat diketahui bahwa sebelum diberikan konseling, jumlah subjek yang mengetahui tentang ASI ekslusif paling banyak pada kelompok kontrol yaitu 80,0 persen, sedangkan setelah diberi konseling sebagian besar kelompok intervensi dan kontrol mengetahui tentang ASI ekslusif yaitu 100 persen. Sebanyak 70,0 persen pada kelompok konseling mengetahui pengertian ASI ekslusif sebelum diberi konseling, namun setelah diberi konseling pengetahuan meningkat pada kelompok kontrol sebanyak 90,0 persen. Dari pertanyaan manfaat ASI sebanyak 46,7 persen subjek kelompok intervensi memilih semua benar. Sebelum diberikan konseling, sebanyak 63,3 persen subjek kelompok intervensi tidak mengetahui tentang ASI pertama yang keluar, dan setelah diberi konseling sebanyak 56,7 persen mengetahui tentang ASI pertama yang keluar. Dari pertanyaan manfaat kolostrum sebanyak 70,0 persen subjek kelompok intervensi memilih meningkatkan daya tahan tubuh.

\section{BAHASAN}

Pemenuhan gizi ibu hamil dan menyusui menjadi suatu hal yang perlu diperhatikan. Hal ini terkait dengan periode emas perkembangan dan pertumbuhan, yaitu dimulai dari masa awal kehidupan dari pada saat di di dalam kandungan hingga dua tahun pertama. Kesehatan, status gizi dan asupan ibu pada periode tersebut sangat perlu dijaga, karena pada 1000 hari pertama kehidupan adalah saat dimana organ-organ penting mulai terbentuk dan berkembang. ${ }^{17}$ Salah satu usaha untuk mencapai 1000 hari kehidupan yang optimal adalah dengan pemberian ASI eksklusif. ASI mengandung zat gizi lengkap yang dibutuhkan 
oleh bayi, meningkatkan imunitas, mencegah penyakit infeksi, dan mencegah peningkatan mortalitas ibu dan bayi lahir. ${ }^{3}$ Namun cakupan ASI eksklusif masih belum mencapai angka target. $^{6-8}$ Kesukseskan pemberian ASI eksklusif yang dipengaruhi oleh pengetahuan, pendidikan, dukungan orang terdekat, informasi dari pertugas kesehatan, dan budaya pemberian ASI eksklusif. ${ }^{9}$

Karakteristik ibu didominasi oleh ibu yang berusia di bawah 30 tahun, tinggal di daerah perkotaan, berpendidikan tinggi, merupakan lbu rumah tangga, dan berpenghasilan < Rp 500.000. Dalam penelitian ini tidak ada perbedaan antara kelompok intervensi dan kelompok kontrol $(p>0,05)$ (Tabel 1). Status gizi ibu diukur ketika 1 bulan setelah kelahiran. Proporsi status gizi lebih (overweight dan obesitas) ibu pada kelompok intervensi cenderung lebih banyak dibandingkan dengan kelompok kontrol, hal ini juga terlihat pada status gizi kurang lebih banyak terdapat pada kelompok kontrol. Status gizi bukan merupkan indikator yang baik dalam menentukan status gizi, namun IMT pada ibu menyusui dapat menggambarkan status gizi saat ini.

lbu harus dapat menjaga status gizinya agar dapat memberikan ASI yang maksimal untuk buah hatinya. Ibu dengan gizi buruk umumnya memproduksi ASI dalam jumlah yang lebih sedikit, tetapi kualitasnya tergantung pada makanan yang dimakan, umumnya terdapat penurunan kadar lemak, karbohidrat dan vitamin. ${ }^{18}$ Sebaliknya ibu yang mempunyai gizi buruk akan mempengaruhi kecukupan ASI karena tubuh membutuhkan zat gizi yang cukup untuk memproduksi ASI tetapi tubuh tidak dapat memenuhi sehingga zat gizi tersebut diambil dari tubuh ibu sehingga makin lama ibu akan mengalami gizi yang bertambah buruk. Ada hubungan antara status gizi ibu menyusui dengan kecukupan ASI. ${ }^{19}$

Persentase kecukupan energi ibu hanya mencapai 78-79 persen dari EAR. Angka ini masih dalam kategori kurang $(<80 \%$ kebutuhan). Kecukupan zat gizi makro yang lain masih dalam kategori kurang, karena sebagian besar masih di bawah 80 persen kebutuhan. Angka ini sejalan dengan systematic review mengenai asupan ibu hamil di Indoensia bahwa tidak hanya asupan ibu menyusui, kecukupan asupan ibu hamil di Indonesia masih di bawah EAR. ${ }^{20}$ Jika kebutuhan ibu hamil sudah kurang, pemenuhan kebutuhan ibu saat menyusui juga akan sulit dipenuhi.

Pemenuhan asupan ibu sangat penting karena penyerapan zat-zat gizi lainnya seperti vitamin dan mineral akan lebih maksimal jika pemenuhan makronya mencukupi. Hasil ini sesuai dengan penelitian ibu hamil di Bogor bahwa defisiensi asupan gizi makro ditemukan pada 44 persen ibu hamil dan defisiensi zat besi sebesar 85 persen, walaupun variasi makan sayur buah dan susu tinggi. ${ }^{21} \mathrm{Hal}$ ini juga berkaitan dengan 1000 HPK (Hari Pertama Kehidupan). Pemenuhan kebutuhan gizi ibu dimulai dari saat awal hamil hingga bayi berusia 2 tahun, karena pada masa itulah terjadi perkembangan dan pertumbuhan organ-organ dan fungsi pada bayi yang akan dilahirkan. ${ }^{22}$

Ibu hamil mengalami peningkatan kebutuhan dikarenakan ada perubahan secara fisiologis dan untuk kebutuhan pada janinnya, meliputi asupan energi, asupan protein, dan besi serta zat gizi mikro harus terpenuhi. Ketika asupan tidak mencukupi, tubuh akan mengalami kekurangan energi untuk menjaga stabilisasi metabolisme tubuh begitu pula pada saat menyusui, ibu membutuhkan zat gizi tambahan untuk mempertahankan kesehatan dan untuk memproduksi ASI. Menurut Salam et al disebutkan bahwa rata-rata tingkat kecukupan asupan protein, seng, dan besi mengalami penurunan bermakna setelah tiga bulan ibu melahirkan. ${ }^{23}$

Pengetahuan ibu terkait kesehatan ibu dan menyusui masih rendah yaitu sebesar 51,8 persen dan 54,8 persen. ${ }^{10,24}$ Peningkatan pengetahuan ini penting untuk memastikan pengetahuan awal ibu sebelum mengaplikasikan ke dalam praktek pemberian ASI. Penelitian di Yogyakarta menyebutkan ada hubungan signifikan antara pengetahuan dengan keberhasilan ASI eksklusif $(p<0,05) .{ }^{11}$ Berdasarkan hasil uji statistik didapatkan bahwa sebelum diberikan intervensi konseling, ratarata skor pengetahuan antara kelompok intervensi dengan kelompok kontrol tidak berbeda secara bermakna $(p>0,05)$. Pada akhir intervensi, terdapat peningkatan skor pengetahuan secara bermakna pada kedua kelompok. Terdapat perbedaan skor pengetahuan yang bermakna sesudah intervensi antara kelompok intervensi $(p<0,001)$, dengan skor pengetahuan lebih besar pada kelompok kontrol. 
Pada kelompok kontrol, konseling menyusui dilakukan oleh bidan, tanpa mendapatkan tambahan mengenai materi gizi, sementara kelompok intervensi mendapatkan konseling dari tenaga gizi yang terlatih. Proses konseling menggambarkan adanya kerjasama antara konselor dengan klien dalam mencari tahu tentang masalah yang dihadapi klien. Proses ini memerlukan keterbukaan dari klien dan konselor agar mencapai jalan keluar pemecahan masalah klien. ${ }^{25}$ Dalam menggali informasi klien dan membangun kepercayaan klien untuk terbuka membutuhkan pengalaman, yang dalam penelitian ini lebih dimiliki oleh bidan dalam memberikan konseling mengenai ASl eksklusif.

Berdasarkan analisis per item pertanyaan mengenai pengetahuan ASI. Secara keseluruhan baik kelompok kontrol maupun kelompok intervensi yang mendapatkan konseling menyusui mengalami peningkatan dari semua item pertanyaan, namun ada perbedaan peningkatan yang lebih besar pada poin pengertian ASI ekslusif, dan manfaat pemberian ASI. Pengetahuan mengenai ASI pertama dan kolostrum peningkatannya lebih besar pada kelompok kontrol. Adanya peningkatan pengetahuan pada kelompok kontrol dapat dikarenakan kelompok kontrol sudah mendapatkan paparan informasi yang media maupun sumber lain seperti website, aplikasi daring dan video yang saat ini sudah bisa diakses lebih mudah dan dalam penelitian ini tidak diteliti.

Ada perubahan yang bermakna pada asupan energi, protein dan karbohidrat antara sebelum dan sesudah diberikan intervensi, bahwa asupan setelah intervensi terdapat peningkatan pada kedua kelompok, sedangkan tidak untuk asupan lemak. Dari keseluruhan asupan tidak ada perbedaan antara kelompok intervensi dan kelompok kontrol, namun ada kecenderungan peningkatan asupan yang lebih besar pada kelompok intervensi yaitu yang diberikan tambahan konseling mengenai gizi.

Perubahan asupan atau perilaku makan adalah hal yang sulit untuk dilakukan. Dalam penelitian Nisa tahun 2018, bahwa tidak ada perubahan asupan wanita usia subur setelah diberikan konseling pra-konsepsi. ${ }^{26}$ Perubahan perilaku membutuhkan tahapan. Menurut Health Believe Model, perubahan terdiri dari perceived susceptibility (kepercayaan), perceived severity (persepsi mengenai keseriusan masalah), perceived benefits (persepsi bahwa perubahan akan mengurangi akibat), dan perceived barriers (persepsi bahwa untuk mengubah perubahan harus melewati kendala). ${ }^{27,28}$

Keberhasilan konseling dalam pelaksanaannya ditentukan oleh banyak faktor, antara lain struktur, inisiatif, tatanan (setting) fisik, kualitas klien dan kualitas konselor. ${ }^{29}$ Selain itu ada faktor individual, faktor interaksi, faktor situasional seperti kondisi lingkungan dan faktor kompetensi dalam melakukan percakapan, yang jika salah satu faktor tidak terpenuhi, maka informasi yang disampaikan akan berbeda. Dalam studi ini peneliti hanya mengukur variabel pengetahuan dan asupannya saja, sehingga beberapa aspek terkait perubahan perilaku belum dapat di bahas secara mendalam. Namun yang pasti, peningkatan pengetahuan ini merupakan sebuah titik awal untuk perubahan perilaku terutama dalam pemberian ASI Eksklusif.

\section{SIMPULAN DAN SARAN}

\section{Simpulan}

Pemberian konseling menyusui selama 3 kali dalam 3 bulan dapat meningkatkan pengetahuan ibu dalam hal pemberian ASI eksklusif $(p<0,001)$.

\section{Saran}

Sebaiknya edukasi dan konseling bagi ibu menyusui disampaikan oleh bidan dan ahli gizi serta melibatkan kehadiran suami, orangtua atau mertua sehingga edukasi dan konseling yang diberikan dapat dijalankan dengan optimal. Pada penelitian berikutnya perlu diteliti mengenai sikap dan motivasi ibu dalam pemberian ASI eksklusif beserta pengaruhnya terhadap pemberian ASI.

\section{RUJUKAN}

1. Kementerian Kesehatan. Infodatin : Menyusui sebagai Dasar Kehidupan. Pusat Data Informasi Kesehatan [Internet]. 2018. Available from: https://www.kemkes.go.id/ download.php?file=download/pusdatin/i nfodatin/infodatin ASI per halaman 02012018.pdf

2. Yuliarti N. Keajaiban ASI. Yogyakarta: 
Penerbit Andi; 2010.

3. Yandra RF. Hubungan Pemberian ASI Eksklusif Dengan Kejadian Diare Akut Pada Bayi Usia 1-6 Bulan Di Wilayah Kerja Puskesmas Pucangsawit Surakarta. Universitas Muhammadiyah Surakarta; 2014.

4. Human Development Report. The Real Wealth of Nations: Pathways to Human Development [Internet]. United Nations Development Programme (UNDP). 2010 [cited 2020 Dec 21]. Available from:

http://hdr.undp.org/en/content/humandevelopment-report-2010

5. Direktorat Kesehatan Keluarga. Laporan Tahunan Direktorat Kesehatan Keluarga tahun 2016. Jakarta; 2016.

6. Kementerian Kesehatan. Profil Kesehatan Indonesia 2018 [Internet]. Jakarta; 2018. Available from: https://pusdatin.kemkes.go.id/ resources/download/pusdatin/profilkesehatanindonesia/PROFIL_KESEHATAN_2018 _1.pdf

7. Kementerian Kesehatan. Profil Kesehatan Indonesia 2019 [Internet]. Jakarta; 2019. Available from: https://pusdatin.kemkes.go.id/ resources/download/pusdatin/profilkesehatanindonesia/PROFIL_KESEHATAN_2019 _1.pdf

8. Kementerian Kesehatan. Rencana Strategis Kementerian Kesehatan Tahun 2015-2019 [Internet]. Jakarta; 2015 [cited 2020 Dec 21]. Available from:

https://www.kemkes.go.id/resources/do wnload/info-publik/Renstra-2015.pdf.

9. Karim UN, Djafar M. Faktor -Faktor yang Berhubungan dengan ibu dalam Pemberian Asi Eksklusif Pada Bayi di Puskesmas Jailolo Kabupaten Halmahera Barat Propinsi Maluku Utara Tahun 2017. J Teknol Bank Darah. 2017;1(2):60-9.

10. Lestari RR. Faktor-Faktor yang Berhubungan dengan Pemberian ASI Ekslusif pada Ibu. J Obs J Pendidik Anak Usia Dini. 2018;2(1):131-6.

11. Khofiyah N. Analisis Faktor-Faktor yang
Mempengaruhi Pemberian ASI Eksklusif di Puskesmas Umbulharjo I Yogyakarta. J Kebidanan [Internet]. 2019 Aug 13;8(2):74. Available from: https://jurnal.unimus.ac.id/index.php/jur _bid/article/view/4250

12. Departemen Kesehatan Republik Indonesia. Pedoman Penyelenggaraan Pelatihan Konseling Menyusui dan Pelatihan Fasilitator Konseling Menyusui. Jakarta; 2007.

13. Eugenie T, Batlejeri J, Napitupulu M. Pengetahuan ibu merupakan faktor dominan dalam pemberian asi eksklusif. J IImiu dan Teknol Kesehat. 2015;2(2):27-33.

14. Liliana A, Hapsari ED, Nisman WA. Pengaruh konseling laktasi terhadap pengetahuan, kemampuan dan keberhasilan ibu dalam pemberian ASI. Ber Kedokt Masy [Internet]. 2017 Feb 1;33(2):91. Available from: https://jurnal.ugm.ac.id/bkm/article/view/ 13216

15. Lina. Pengaruh Konseling Menyusui terhadap pemberian ASI Eksklusif di Kabupaten Aceh Timur Tahun 2012. Universitas Sumatera Utara; 2012.

16. Notoatmodjo S. Pendidikan dan Perilaku Kesehatan. Jakarta: Rineka Cipta; 2003.

17. Sudargo T, Aristasari T, 'Afifah A. 1000 hari pertama kehidupan. Yogyakarta: Gama Press; 2018.

18. Irawan R. Pola dasar makanan bayi dan anak. Surabaya; 2003.

19. Pujiastuti N. Korelasi antara status gizi ibu menyusui dengan kecukupan asi di posyandu desa karang kedawang kecamatan sooko kabupaten mojokerto. J Keperawatan [Internet]. 2010 Dec 29;1(2). Available from: http://ejournal.umm.ac.id/index.php/kep erawatan/article/view/407

20. Hartriyanti $Y$, Suyoto PST, Muhammad HFL, Palupi IR. Nutrient intake of pregnant women in Indonesia: a review. Malays J Nutr [Internet]. 2012 Apr;18(1):113-24. Available from: http://www.ncbi.nlm.nih.gov/pubmed/23 713235

21. Madanijah $S$, Briawan D, Rimbawan R, Zulaikhah Z, Andarwulan N, Nuraida L, 
et al. Nutritional status of pre-pregnant and pregnant women residing in Bogor district, Indonesia: a cross-sectional dietary and nutrient intake study. $\mathrm{Br} J$ Nutr [Internet]. 2016 Jul 15;116(S1):S57-66. Available from: https://www.cambridge.org/core/product lidentifier/S000711451600057X/type/jou rnal_article

22. Rahayu A, Rahman $F$, Marlinae $L$, Husaini $H$, Meitria M, Yulidasari F, et al. Buku Ajar Gizi 1000 Hari Pertama Kehidupan. Yogyakarta: CV Mine; 2018.

23. Salam A, Briawan D, Martianto D, Thaha AR. Pengaruh Konseling Mengenai Gizi Prakonsepsi Terhadap Asupan Protein, Kalsium, Zat Besi, Asam Folat dan Status Gizi pada Wanita Usia Subur di Kelurahan Paluh Kemiri. Media Gizi Indones [Internet]. 2020 May 6;15(2):127. Available from: https://e-

journal.unair.ac.id/MGI/article/view/1439 0

24. Pitaloka DA, Abrory R, Pramita AD. Hubungan antara Pengetahuan dan Pendidikan Ibu dengan Pemberian ASI Eksklusif di Desa Kedungrejo Kecamatan Waru Kabupaten Sidoarjo. Amerta Nutr [Internet]. 2018 Aug 27;2(3):265. Available from: https://ejournal.unair.ac.id/AMNT/article/view/90 25
25. Mulawarman M, Nugraheni EP, Putri A, Febrianti T. Psikologi Konseling: Sebuah Pengantar bagi Konselor Pendidikan. Jakarta: Prenada Media; 2019.

26. Nisa K. Pengaruh Konseling Mengenai Gizi Prakonsepsi Terhadap Asupan Protein, Kalsium, Zat Besi, Asam Folat dan Status Gizi pada Wanita Usia Subur di Kelurahan Paluh Kemiri. Poltekkes Medan; 2019.

27. Denison J. Behavior change: a summary of four major theories, Family Health International (FHI) [Internet]. 1996 [cited 2020 Dec 21]. Available from:

https://www.fhi360.org/resource/behavio $r$-change-summary-four-major-theories

28. Jones $\mathrm{CL}$, Jensen JD, Scherr $\mathrm{CL}$, Brown NR, Christy K, Weaver J. The Health Belief Model as an Explanatory Framework in Communication Research: Exploring Parallel, Serial, and Moderated Mediation. Health Commun [Internet]. 2015 Jun 3;30(6):566-76. Available from: http://www.tandfonline.com/doi/abs/10.1 080/10410236.2013.873363

29. Gladding ST. Konseling Profesi yang Menyeluruh. Jakarta: PT Indek; 2012. 